\title{
Mitochondrial impairments in aetiopathology of multifactorial diseases: common origin but individual outcomes in context of $3 \mathrm{P}$ medicine
}

\author{
Lenka Koklesova $^{1} \cdot$ Marek Samec $^{1} \cdot$ Alena Liskova $^{1} \cdot$ Kevin Zhai $^{2} \cdot$ Dietrich Büsselberg $^{2} \cdot$ Frank A. Giordano $^{3}$. \\ Peter Kubatka $^{4}$ - Olga Golunitschaja ${ }^{5}$
}

Received: 9 February 2021 / Accepted: 11 February 2021 / Published online: 4 March 2021

(C) The Author(s) 2021

\begin{abstract}
Mitochondrial injury plays a key role in the aetiopathology of multifactorial diseases exhibiting a "vicious circle" characteristic for pathomechanisms of the mitochondrial and multi-organ damage frequently developed in a reciprocal manner. Although the origin of the damage is common (uncontrolled ROS release, diminished energy production and extensive oxidative stress to lifeimportant biomolecules such as mtDNA and chrDNA), individual outcomes differ significantly representing a spectrum of associated pathologies including but not restricted to neurodegeneration, cardiovascular diseases and cancers. Contextually, the role of predictive, preventive and personalised (PPPM/3P) medicine is to introduce predictive analytical approaches which allow for distinguishing between individual outcomes under circumstance of mitochondrial impairments followed by costeffective targeted prevention and personalisation of medical services. Current article considers innovative concepts and analytical instruments to advance management of mitochondriopathies and associated pathologies.
\end{abstract}

Keywords Mitochondrial impairment · Injury $\cdot$ ROS $\cdot$ Energy imbalance $\cdot$ Vicious circle $\cdot$ Oxidative stress · Aetiopathology multi-organ dysfunction $\cdot$ Suboptimal health $\cdot$ Reversible damage $\cdot$ Vasospasm $\cdot$ Mitigating measures $\cdot$ Repair $\cdot$ Mechanisms Multifactorial disease · Ageing · Neurodegeneration · Glaucoma · Alzheimer · Cancer - Cardiovascular disease · Predictive preventive personalised medicine $(\mathrm{PPPM} / 3 \mathrm{PM}) \cdot$ Multi-modal diagnostics $\cdot$ Liquid biopsy $\cdot$ Molecular patterns $\cdot$ Biomarker panel $\cdot$ Patient stratification · Individualised patient profiling · Origin · Outcomes $\cdot$ Complementary medicine $\cdot$ Health policy . Cost efficacy $\cdot$ COVID-19

Olga Golunitschaja

olga.golubnitschaja@ukbonn.de

1 Department of Obstetrics and Gynaecology, Jessenius Faculty of Medicine, Comenius University in Bratislava, 036

01 Martin, Slovakia

2 Department of Physiology and Biophysics, Weill Cornell Medicine-Qatar, Education City, Qatar Foundation, Doha 24144, Qatar

3 Department of Radiation Oncology, University Hospital Bonn, Rheinische Friedrich-Wilhelms-Universität Bonn, 53127 Bonn, Germany

4 Department of Medical Biology, Jessenius Faculty of Medicine, Comenius University in Bratislava, 03601 Martin, Slovakia

5 Predictive, Preventive, Personalised (3P) Medicine, Department of Radiation Oncology, University Hospital Bonn, Rheinische Friedrich-Wilhelms-Universität Bonn, 53127 Bonn, Germany

\section{Introduction}

\section{"Vicious circle" of the mitochondrial injury and multi- organ dysfunction}

Mitochondria are semi-autonomous organelles of prokaryotic origin [1], with outer and inner membranes encapsulating the intermembrane space and matrix compartments [2]. Proper mitochondrial physiology is essential for maintaining physical and mental health. Mitochondria primarily act as the main energy supplier through oxidative phosphorylation (OXPHOS) and therefore directly influencing the efficacy of highly energyconsuming repair process in the cell [3]. Mitochondria are involved in regulation of ion homeostasis, redox potential, lipid metabolism, metabolite synthesis, cell differentiation, immune system as well as anti-apoptotic and anti-ageing processes, amongst others [4-9].

The mitochondrial genome is represented by $16,569 \mathrm{bp}$ mitochondrial DNA (mtDNA). In animals and humans, inheritance 
of mtDNA is considered to be exclusively of maternal origin [10]. Accumulation of mtDNA mutations is associated with accelerated ageing and development of ageing-associated pathologies such as neurological disorders, cardiovascular diseases (CVDs), metabolic syndromes and cancers [3, 10]. Mitochondrial impairments (known also as mitochondriopathies) can be inherited (through an autosome and/or X chromosome maternally) or developed in a multi-factorial way including but not restricted to a toxic environment, sub-optimal health conditions and collateral pathologies (such as metabolic syndrome) [3]. Mitochondriopathies carry systemic character and can be damaging for many organs [11]. Molecular interplay shifted towards excessive ROS formation, but diminished energy production is a critical "vicious circle" of the mitochondrial injury and multi-organ dysfunction which can be developed in a reciprocal manner [3]. By insufficient energy production, chronic exposure to ROS overproduction consequently leads to the oxidative damage of life-important biomolecules including nucleic acids, proteins, lipids and amino acids, amongst others. Consequently, mitochondrial dysfunction is associated with accelerated ageing, neurodegeneration, tumourigenesis, metabolic syndromes and mood disorders, amongst others [3]. As the multi-factorial disorder of different severity grade, mitochondriopathies are remarkably heterogeneous being, therefore, challenging for overall clinical management.

Regarding diagnostics, since different forms of mitochondrial dysfunction may affect the brain, heart, peripheral nervous and endocrine systems, eyes, ears, guts and kidney, amongst other organs, mitochondriopathies have been proposed as an attractive diagnostic target to be investigated in any patient with unexplained progressive multisystem disorder [3].

Approaches to treat neurodegenerative disorders such as Alzheimer's disease and glaucoma include standardised ginkgo biloba extract (EGb761®), piracetam and Dimebon, which are known to address many aspects of mitochondrial functionality such as mitochondrial dynamics [11]. Further, generalised approaches such as physical exercise demonstrating neuroprotective [12], cardioprotective [13-18] and anti-cancer [19] effects are clearly associated with the mitochondrial function support. Finally, phytochemicals, naturally occurring compounds, used due to their neuroprotective, cardioprotective and anticarcinogenic effects, have been demonstrated as a modulator of the mitochondrial function, structure and related mechanisms [20-27].

\section{Mitochondriopathies in focus of predictive approach, targeted prevention and personalisation of medical services}

Mitochondriopathies, concomitant multi-organ damage and associated broad spectrum of chronic disorders cause enormous socio-economic burden. Contextually, the paradigm change from reactive medicine to PPPM strategies is strongly recommended to advance healthcare in the area [28].

Due to absent causative therapies and cure for individual forms of mitochondriopathies, predictive approaches, individualised patient profiling, targeted prevention and personalisation of medical services are instrumental for the overall management of mitochondriopathies.

This article details pathomechanisms related to mitochondrial injury as the clue to multi-factorial disorders and exemplifies conditions and tools to be considered at the clinical side, in order to identify predisposed individuals and to introduce targeted mitigating measures against potential mitochondriopathy and cascaded development of related pathologies.

\section{Multifunctionality of mitochondria in maintaining physical and mental health versus disease development}

Mitochondria perform an essential role in eukaryotic organisms with important cellular functions, especially in energy metabolism, and also in synthetic and oxidation/reduction processes, ionic regulation (e.g. calcium homeostasis) and signalling pathways connected to cell communication, survival and death $[4-7,10]$. The key role of mitochondria in the physiology of cells needed for maintaining physical and mental health is summarised in Fig. 1. To this end, as described for a broad spectrum of cell types, mitochondria are highly heterogeneous considering their morphology and functionality that should be kept in mind considering tissue and organ specificity [29].

Human mitochondria contain 16,569 bp circular DNA which encodes 37 genes for ribonucleic acids (RNAs) and protein subunits of the respiratory chain [30]. Noteworthy, mtDNA usually demonstrates higher mutation rates compared with these of chromosomal DNA; accumulation of mtDNA mutations has been related to ageing and age-associated diseases [31]. Being the major producers of reactive oxygen species (ROS) in the cell, mitochondria are extensively exposed to the oxidative damage [32]. However, under physiologic condition, controlled production of ROS, sufficient energy supply and efficient repair performance are well-balanced together [3]. Under this condition, mtDNA, damaged by oxidative stress, can be effectively repaired through base excision repair (BER) to restore mitochondrial genome integrity. In contrast, under the "vicious circle" circumstances, uncontrolled ROS overproduction accompanied with diminished energy supply and repair machinery insufficiency collectively results in extensive mutations within the mtDNA including genes responsible for the BER pathway and mitochondrial repair enzymatic activities; irreversible changes in mitochondrial dynamics, including mitochondrial fusion/fission, 


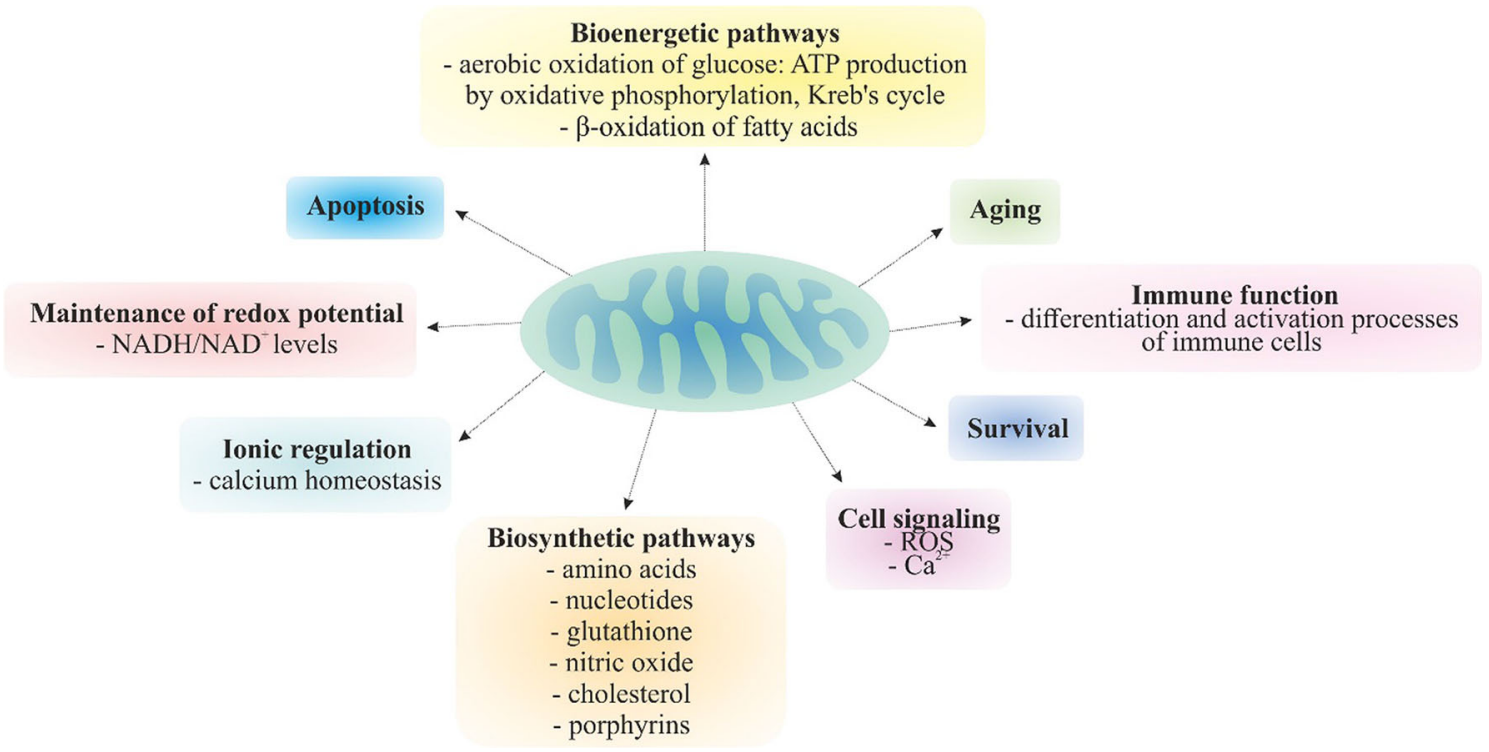

Fig. 1 Mitochondrial function in the cell

motility, morphology, size and transport [33]; and irreversible damage to life-important biomolecules and development of associated diseases [3]. Figure 2 presents molecular mechanisms and factors responsible for mitochondrial impairments associated with a spectrum of neurodegenerative disabilities, CVDs and cancers.

Declined mitochondrial qualities and activities are associated with multi-faceted ageing processes; in turn, ageingrelated accumulation of mitochondrial mutations predisposes affected individual to a wide range of related disorders such as metabolic syndromes, cancers, CVDs and multiple neurodegeneration [34]. Mitochondrial ageing observed in associated disorders is characterised by the reciprocal relationship between the decreased respiratory capacity and uncontrolled ROS overproduction leading to strongly pronounced oxidative stress, increased pyruvate oxidation, telomere shortening, lipid toxicity and metabolic disturbances such as reduced both an activity of citrate synthase and phosphocreatine recovery time and, finally, dysfunctional mitochondrial quality control machinery (seen, e.g. in autophagy) $[35,36]$.

\section{Mitochondrial impairments characteristic for neurodegeneration}

Progressive neurodegeneration causes neuronal death and synapse loss in vulnerable areas of the spinal cord and brain as well as visual impairments and blindness by retinal diseases. Regarding the latter, oxidative stress and associated mitochondrial dysfunction are integral components of the aetiopathology of retinal diseases, including diabetic retinopathy, age-related macular degeneration and glaucoma [37]. Both non-modifiable and modifiable (preventable) multi- factorial risk factors are involved in neurodegenerative process including by not restricted to the genetic predisposition, suboptimal health conditions, toxic environment, endogenous and exogenous stress, systemic ischemia-reperfusion and mitochondrial vulnerability, which individually or collectively may lead to irreversible damage and degeneration of neuronal systems [38-40].

In glaucomatous optic nerve degeneration considered the second leading cause of blindness in human beings, currently affecting around 70 million patients worldwide, an oxidative stress by ischemia-reperfusion linked to mitochondrial impairments, insufficient DNA repair and neuronal damage, amongst other related processes has been demonstrated as belonging to the comprehensive aetiopathology of the disease $[41,42]$. Further, as detailed specifically for the normaltension glaucoma, an imbalanced vasoconstriction in response to multi-factorial stimuli (such as cold provocation, hormonal and emotional stress) plays a central role in systemic ischemia-reperfusion damage and can be observed early in life of persons with suboptimal health conditions such as vasospastic individuals [43]. Consequently, the subpopulation of young vasospastic individuals demonstrating reversible systemic damages is considered as a potent target for innovative screening programmes and application of predictive diagnosis, cost-effective targeted prevention and treatment algorithms tailored to the personalised patient profiles [44].

Alzheimer's disease is one of the most prominent examples of a multi-factorial neurodegenerative disorder related to oxidative stress and mitochondrial dysfunction with high morbidity and mortality registered worldwide [45]. At early pathological events, synaptic damage correlates strongly with cognitive deficits and memory loss. Alzheimer's disease is related to the increased production and impaired clearance of self- 


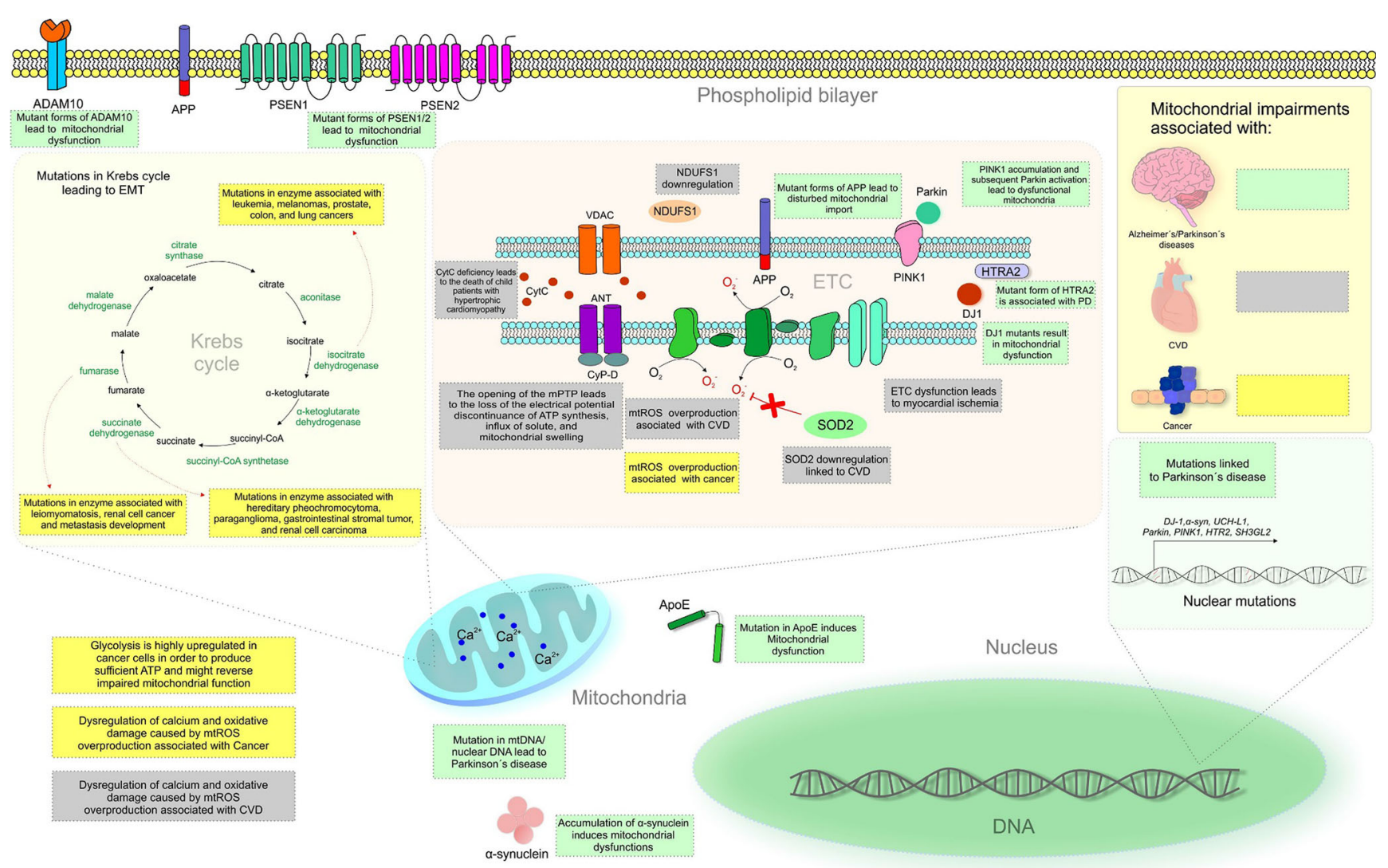

Fig. 2 Molecular mechanisms and factors associated with mitochondrial impairments in neurodegenerative and cardiovascular diseases, and cancer. ADAM10, a disintegrin and 71 metalloprotease 10; APP, amyloid precursor protein; PSEN1, presenilin 1; PSEN2, presenilin 2; EMT, epithelial-mesenchymal transition; mtROS, mitochondrial reactive oxygen species; CVD, cardiovascular disease; DNA, deoxyribonucleic acid; ApoE, apolipoprotein E; SOD2, superoxide dismutase 2; ETC, electron transport chain; DJ1, parkin-associated protein involved with

aggregating forms of $\beta$-amyloid [46]. Moreover, mtDNA frequently encodes ETC components; therefore, mtDNA mutations lead to increased mitochondrial energetic dysfunction [47]. Besides, various gene mutations closely associated with mitochondrial function, including those involving amyloid precursor protein $(A P P)$, presenilin 1 (PSEN1), 46 presenilin 2 (PSEN2), apolipoprotein E (ApoE) and a disintegrin and 71 metalloprotease 10 (ADAM10), lead to Alzheimer's disease [48]. APP accumulated in mitochondrial protein import channels interacts with various mitochondrial proteins and leads to mitochondrial dysfunction [49]. Moreover, neuronal damage or stress leads to ApoE synthesis. In neurons, the specific conformation of ApoE4 is susceptible to proteolysis, resulting in pathological mitochondrial dysfunction and cytoskeletal alterations [50]. PSEN mutations enhance neurodegeneration mediated by endoplasmic reticulum-mitochondria calcium transfer [51]. Finally, mutations in ADAM10 increase $\beta$ amyloid production and mitochondrial impairment associated with Alzheimer's disease pathogenesis [52]. oxidative stress; HTRA2, serine peptidase 2; PD, Parkinson's disease; mPTP, mitochondrial permeability transition pore; ATP, adenosine triphosphate; PINK1, putative serine threonine kinase; CytC, cytochrome $c$; ANT, adenine nucleotide translocator; CyPD, cyclophilin D; NDUFS1, anti-oxidative enzyme superoxide dismutase 2 and complex I subunit; VDAC, voltage-dependent anion channel; Parkin, E3 ubiquitin ligase; $\alpha$-syn, $\alpha$-synuclein; UCH-L1, ubiquitin carboxy-terminal hydrolase L1; SH3GL2, SH3 domain containing GRB2 like 2/endophilin A1

Parkinson's disease affects about $2 \%$ of the population above the age of 60 years [53]. Parkinson's disease is characterised by the loss of dopaminergic neurons in the substantia nigra pars compacta (SNpc) and the presence of misfolded $\alpha$-synuclein $(\alpha$-syn) in intra-cytoplasmic inclusions known as Lewy bodies [54]. Mutations in mtDNA or nuclear DNA, including those involving E3 ubiquitin ligase (Parkin), $\alpha$-syn, ubiquitin carboxy-terminal hydrolase L1 (UCHL1), parkin-associated protein involved with oxidative stress $(D J 1)$, putative serine threonine kinase (PINK1), auxilin (DNAJC6), synaptojanin 1 (SYNJ1), serine peptidase 2 (HTRA2) and endophilin A1 (SH3GL2), are described in the pathogenesis of Parkinson's disease [55-59]. These genes are important for mitochondrial function, and mutations or disturbances in function can lead to mitochondrial impairments. $\alpha$-syn controls mitochondrial function under both physiological and pathological conditions. Mutations in $\alpha$-syn contribute to neuronal impairment in Parkinson's disease [60]. DJ1 encodes a ubiquitous, highly conserved protein. DJ1 is an integral mitochondrial protein that 
maintains the activity of mitochondrial complex I and regulates mitochondrial homeostasis [61]. Moreover, the accumulation of PINK1 on defective mitochondria leads to the translocation of Parkin from the cytosol to eliminate damaged mitochondria through mitophagy (the selective degradation of mitochondria by autophagy) [62]. Disruptions in mitochondrial homeostasis or the expression of PINK1 and Parkin leads to mitochondrial impairments and associated disorders such as Parkinson's disease. Moreover, HTRA2 is a mitochondrial protein with a proteolytic role in protein quality control and homeostasis in the mitochondrial intermembrane space. Mutations in HTRA2 are associated with autosomal dominant late-onset Parkinson's disease [63]. Furthermore, UCHL1 is a key enzyme in the protein degradation pathway and functions in the physiological remodelling of synapses by controlling ubiquitin homeostasis. Any disturbance in homeostasis contributes to mitochondrial and synaptic failure [64]. Finally, DNAJC6, SYNJ1 and SH3GL2 are associated with the disruption of synaptic vesicle endocytosis, which contributes to mitochondrial dysfunction and is thus related to the pathogenesis of Parkinson's disease.

\section{Mitochondrial impairments characteristic for cardiovascular diseases}

CVDs, a prevalent cause of morbidity and mortality worldwide, comprise heart and circulatory system disorders which result mainly from atherosclerosis and manifest as heart attacks and strokes $[65,66]$. CVDs are highly heterogeneous and chronic diseases which may remain asymptomatic for a long time [67]. Several factors are responsible for the development of CVDs including invariable factors, such as gender, age and genetic heritage, versus variable factors, such as sedentary life-style, tobacco use, obesity, inappropriate eating habits, high blood pressure and preventable metabolic syndromes, amongst others [68]. Moreover, there are some gender specific risk factors such as related to female hormonal regulation in peri/menopause and pregnancy [69].

Mitochondria play an important role in cardiac homeostasis. Being highly energy-consuming, cardiomyocytes are rich on mitochondria. Deficient ATP synthesis and energy metabolism contribute in a reciprocal way to disturbed cardiac excitation-contraction, severe mitochondrial impairments and development of CVDs, including atherosclerosis, ischemic heart disease, cardiac hypertrophy and heart failure [70-72]. Mitochondrial impairments associated with CVDs are characterised by enhanced ROS production, intracellular ATP depletion, extensive cell damage and highly increased cardiomyocyte apoptotic rates [70]. Stress conditions can lead to calcium and ROS overload, resulting in the loss of mitochondrial membrane potential and the consequent release of mitochondrial proteins including cytochrome $c(\mathrm{CytC})[73$, 74]. CytC deficiency in children diagnosed with hypertrophic cardiomyopathy is a known mortality cause [75]. Noteworthy, accumulating mtDNA mutations have been associated with ischemic heart disease, cardiomyopathy, atherosclerotic vascular disease, dysrhythmias and heart failure [76].

Ischemic heart disease, also known as coronary heart disease, is characterised by an inadequate blood supply to the heart caused by the blockage of blood vessels [77]. To this end, insufficient coronary micro-vessel dilatation, coronary microvascular spasms and dysfunction and extravascular compressive forces contribute to chronic and acute forms of ischemic heart disease [77]. Furthermore, damage in the ETC is responsible for severe myocardial ischemia [78]. In stressed cells, mitochondria activate death channels, especially the mitochondrial permeability transition pore (mPTP), which is regulated by several proteins, including the voltage-dependent anion channel (VDAC), the adenine nucleotide translocator (ANT) and cyclophilin D (CypD). The opening of the mPTP immediately disrupts the electrical potential, halting ATP synthesis and causing an influx of solute and mitochondrial swelling [79-81].

ATP depletion is heavily implicated in both ischemic heart disease and heart failure. Heart failure represents a complex clinical syndrome associated with impaired contractile performance of the myocardium and the heart's inability to sufficiently perfuse peripheral tissues [70]. A major reason for heart failure is calcium dysregulation and oxidative damage caused by mtROS overproduction in human patients $[82,83]$. Moreover, significant mtDNA depletion and inhibition of the expression of mtDNA-encoded proteins are observed in the human heart failure [84]. Cardiac metabolism in the pathological state exhibits an increased reliance on glucose and therefore glycolysis [85]. Systolic heart failure can be further associated with hypertension and/or diabetes [86]. Patients with combined chronic heart failure and diabetes mellitus have worse prognoses associated with elevated ROS overproduction but decreased SOD2/NDUFS1 expression rates compared to patients with chronic heart failure without diabetic history [87].

\section{Mitochondrial impairments characteristic for cancers}

In malignancies, metastasis is the main cause of death in more than $90 \%$ of cancer patients [88]. The heterogeneity of cancers and their frequent therapeutic resistance $[89,90]$ are further concerns motivating application of innovative cost-effective approaches by predictive diagnostics of reversible damage, risk assessment, targeted prevention and treatment algorithms tailored to the person $[19,91-96]$ whereas about 5 to $10 \%$ of cancers are caused by inherited predisposition to malignant cell transformation [97]; the majority of cancer cases carry a sporadic character being preventable [19, 93, 98].

Accumulating mtDNA mutations and uncontrolled ROS overproduction are characteristic for solid and haematological 
malignancies [99-103] both associated with genomic instability and irreversible alterations in gene expression patterns and related signalling pathways. Concomitant changes in $\mathrm{Ca}^{2+}$ and oncometabolite concentrations are highly relevant for mitochondrial retrograde signalling, neoplastic transformation and cancer progression [104]. Disturbed homeostasis of mitochondrial energy metabolism is crucial for the malignant cell transformation and metastatic disease known as the Warburg effect and characterised by the switch from OXPHOS to glycolysis [93]. To this end, activation of hypoxia-inducible factor 1 (HIF-1) by oncogenic protein kinase B (AKT) suppresses pyruvate dehydrogenase (PDH) activity [105]. Upregulation of glucose 6-phosphate dehydrogenase, pyruvate kinase M2 and Rad6 and downregulation of succinate dehydrogenase further contribute to higher lactate levels associated with the Warburg effect [106].

Mutations occur to the mitochondrial Krebs cycle genes contribute to tumorigenesis through the epithelial-mesenchymal transition (EMT). Mitochondrial dysfunction (i.e. OXPHOS downregulation) promotes EMT increasing cancer aggressiveness and poor individual outcomes [107]. Mutations in fumarate hydratase inhibit the conversion of fumarate to malate and lead to leiomyomatosis and highly aggressive renal cell cancer with early-stage metastasis [108]. Mutations of the isocitrate dehydrogenase promote oxidative decarboxylation of isocitrate to $\alpha$ ketoglutarate demonstrated for several cancer types including leukaemia, melanoma, and prostate, colon and lung cancers [109]. Mutations in succinate dehydrogenase predispose to pheochromocytoma, paraganglioma and gastrointestinal stromal tumours as well as renal cell carcinoma [110].

\section{Common origin but individual outcomes}

As detailed above, mitochondrial injury and consequently disturbed energy homeostasis and uncontrolled ROS overproduction cause/strongly contribute to neurodegeneration, malignant cell transformation and CVDs. Moreover, a number of disrupted mitochondrial genes are overlapped in the development of all these pathologies. For example, Parkin associated with Parkinson's disease acts also in hepatocellular carcinoma [111]. Aberrantly expressed and methylated $\alpha$-syn, on one hand, can contribute to neuronal impairment in Parkinson's disease [60] and, on the other hand, has been found in different cancer types including melanoma and brain, ovarian, breast and colorectal cancers $[112,113]$.

Upregulation of phosphorylated microtubule-associated protein tau (MAPT) and consequently altered mitochondrial functions are associated with Alzheimer's disease [114]; in cancer, MAPT overexpression is linked to poor prognosis and drug resistance [115]. Mitochondrial impairments, especially dysfunction of respiratory complex II, cause excessive mtROS generation that is known to be involved in the pathogenesis of both-development of familiar and sporadic cancers and neurodegenerative disorders [116]. The paradox is that although the disease origin is common, individually outcomes differ from each other. Below we provide recently collected statistics demonstrating that, for example, neurodegenerative processes seem to protect against cancer development.

Smoking- and non-smoking-associated cancers occur less frequently in patients with Parkinson's disease [117-119]. No associations between Parkinson's disease and nonfatal cancers were observed [120]. A meta-analysis of fifteen studies comprising 346,153 Parkinson's disease cases demonstrated a lower risk of prostate cancer in the Western population [121]. Although Alzheimer's disease and cancer share multiple impairments related to the ATP depletion, mitochondrial injury and decreased PDH activity [121], patients with Alzheimer's disease demonstrate lower cancer risk compared to the general population [122-124]. A large Danish nationwide cohort study revealed inverse associations between Alzheimer's disease and subsequent cancer diagnoses, specifically pronounced for breast cancer and melanoma compared to the general population [125]. No association have been demonstrated between Parkinson's disease and risks for several cancers including breast, digestive system, lung, urinary and reproductive system cancers as well as haematological malignancies [126]. Further statistics demonstrate that cancer patients are at greater risk to develop later on Parkinson's or Alzheimer's disease, in contrast to lower risk to disease on cancer for people affected by neurodegeneration [127]. This phenomenon hypothetically might be explained by side effects of cancer treatments similarly to a highly increased ischemic stroke incidence well-known for patients with the cancer treatment history: for almost all cancers survivors, the risk of stroke increases with time [128].

In summary, neurodegeneration, cancers and CVDs share many common risk factors and molecular pathways related to mitochondrial function and impairments [129-131]. However, still individual areas undergo rather separate investigations that limits their analytical power and create barriers in development of personalised predictive diagnostics and application of costeffective targeted prevention. Consequently, it is strongly recommended to reconsider future analytical strategies in favour of more comprehensive approaches aiming at multi-modal diagnostics which allow for prediction of individual outcomes under circumstances of mitochondrial impairments [3].

\section{Liquid biopsy is instrumental for individualised diagnostics and prediction of pathologies associated with mitochondriopathies}

Table 1 summarises the research focusing on potential biomarkers obtained from liquid biopsy that are important for 
Table 1 Liquid biopsy in individualised diagnostics and prediction of pathologies associated with mitochondriopathies

\begin{tabular}{|c|c|c|c|c|}
\hline Biomarker & $\begin{array}{l}\text { Type of mitochondrial } \\
\text { disease }\end{array}$ & Fluid sample & Results & Reference \\
\hline mtDNA & \multirow[t]{7}{*}{$\begin{array}{l}\text { Alzheimer's disease } \\
\text { patients }\end{array}$} & \multirow[t]{2}{*}{ Cerebrospinal fluid } & $\begin{array}{l}\downarrow \text { mtDNA in presymptomatic patients } \\
\text { with PSEN1 mutation }\end{array}$ & {$[132]$} \\
\hline ApoE & & & $\uparrow$ ApoE compared to control & {$[133]$} \\
\hline $\begin{array}{l}\text { Oxidant and antioxidant } \\
\text { metabolites }\end{array}$ & & \multirow[t]{2}{*}{ Blood } & $\begin{array}{l}\uparrow \text { Oxidative stress, } \uparrow \text { hydrogen peroxide, } \uparrow \text { organic } \\
\text { hydroperoxides, } \downarrow \text { GSH/GSSG ratio, } \downarrow \text { GSH } \\
\text { transferase, } \downarrow \text { ATP compared to young adult control }\end{array}$ & {$[134]$} \\
\hline Lipofuscin-like pigments & & & $\uparrow$ Lipofuscin-like pigments compared to control & [135] \\
\hline$\beta$-amyloid & & Plasma & $\begin{array}{l}\uparrow \beta \text {-amyloid in Alzheimer's disease patients, } \downarrow \beta \text {-amyloid } \\
\text { after vitamin D treatment, } \downarrow \beta \text {-amyloid-related bio- } \\
\text { markers (A } \beta 42, \text { APP, BACE1, APPmRNA, } \\
\text { BACE1mRNA) }\end{array}$ & {$[136]$} \\
\hline 8-OHdG & & \multirow[t]{2}{*}{ Urine } & $\begin{array}{l}\text { Different levels of 8-OHdG and 2'-deoxyguanosine be- } \\
\text { tween patients with Alzheimer's disease and healthy } \\
\text { control }\end{array}$ & {$[137]$} \\
\hline $\begin{array}{l}\mathrm{AD} 7 \mathrm{C} \text { neural thread } \\
\text { protein }\end{array}$ & & & $\begin{array}{l}\uparrow \text { AD7C neural thread protein in Alzheimer's disease } \\
\text { patients compared to non- Alzheimer's disease } \\
\text { dementia, and healthy normal individuals }\end{array}$ & {$[138]$} \\
\hline DJ1 & \multirow{6}{*}{$\begin{array}{l}\text { Parkinson's disease } \\
\text { patients }\end{array}$} & Cerebrospinal fluid & $\uparrow$ DJ1 compared to control & {$[139]$} \\
\hline $\begin{array}{l}\text { Advanced oxidised } \\
\text { protein products }\end{array}$ & & Cerebrospinal fluid and serum & $\begin{array}{l}\uparrow \text { Advanced oxidised protein products compared to } \\
\text { control }\end{array}$ & {$[140]$} \\
\hline ROS and SOD & & \multirow[t]{2}{*}{ Blood } & $\uparrow$ mtROS in monocytes, $\downarrow$ antioxidant SOD in blood & {$[141]$} \\
\hline Oxidative stress markers & & & $\downarrow$ GSH peroxidase, $\uparrow$ oxidised GSH, $\uparrow$ MDA contents & {$[142]$} \\
\hline Uric acid & & Serum & $\downarrow$ Uric acid & {$[143]$} \\
\hline Biopyrrin & & Urine & $\uparrow$ Biopyrrin compared to control & {$[144]$} \\
\hline ApoC3 & $\begin{array}{l}\text { Coronary heart disease } \\
\text { patients }\end{array}$ & \multirow[t]{2}{*}{ Serum } & $\begin{array}{l}\downarrow \text { ApoC } 3, \downarrow \text { triglyceride after aerobic exercise for } 8 \text { weeks } \\
\text { compared to baseline }\end{array}$ & {$[145]$} \\
\hline Cardiac troponin I & $\begin{array}{l}\text { Patients with acute } \\
\text { decompensated heart } \\
\text { failure }\end{array}$ & & $\begin{array}{l}\uparrow \text { Cardiac troponin I is associated with poor prognosis and } \\
\text { increased mortality }\end{array}$ & {$[146]$} \\
\hline $\begin{array}{l}\text { N-terminal portion of } \\
\text { pro-brain natriuretic } \\
\text { peptide and } \\
\text { adrenomedullin }\end{array}$ & $\begin{array}{l}\text { Ischemic heart disease } \\
\text { patients }\end{array}$ & \multirow[t]{3}{*}{ Plasma } & $\begin{array}{l}\uparrow N \text {-terminal portion of pro-brain natriuretic peptide and } \\
\text { adrenomedullin predict heart failure and death }\end{array}$ & {$[147]$} \\
\hline $\begin{array}{l}\text { Tumour necrosis factor- } \alpha \\
\text { receptor- } 1 \text { and brain } \\
\text { natriuretic peptide }\end{array}$ & $\begin{array}{l}\text { Ischemic heart failure } \\
\text { patients }\end{array}$ & & $\begin{array}{l}\text { Levels are highly predictive for the primary end point of } \\
\text { death or cardiac hospitalisation }\end{array}$ & {$[148]$} \\
\hline D-dimer & $\begin{array}{l}\text { Stroke and coronary heart } \\
\text { disease patients }\end{array}$ & & $\begin{array}{l}\uparrow \text { Basal plasma level of d-dimer is associated with ische- } \\
\text { mic stroke, especially cardioembolic stroke }\end{array}$ & [149] \\
\hline Hsa_circ_0001445 & \multirow[t]{2}{*}{$\begin{array}{l}\text { Coronary artery disease } \\
\text { patients }\end{array}$} & Plasma & $\begin{array}{l}\text { Levels of hsa_circ_0001445 are proportional to coronary } \\
\text { atherosclerotic burden }\end{array}$ & {$[150]$} \\
\hline $\begin{array}{l}\text { Hsa_circ_0001879 and } \\
\text { hsa_circ_0004104 }\end{array}$ & & Blood & $\begin{array}{l}\uparrow \text { hsa_circ_0001879 and hsa_circ_0004104 compared to } \\
\text { control }\end{array}$ & {$[151]$} \\
\hline \multirow[t]{2}{*}{$8 \mathrm{OHdG}$} & Lung cancer patients & \multirow[t]{5}{*}{ Blood } & $\uparrow 8 \mathrm{OHdG}$ compared to healthy control & {$[152]$} \\
\hline & Prostate cancer patients & & $\uparrow 8 \mathrm{OHdG}$ in high-risk patients & {$[153]$} \\
\hline MDA, GSSG, GSH, TAC & Breast cancer patients & & $\begin{array}{l}\uparrow \mathrm{MDA}, \uparrow \mathrm{GSSG}, \downarrow \mathrm{GSH}, \downarrow \mathrm{TAC}, \downarrow \mathrm{GSH} / \mathrm{GSSG} \text { ratio } \\
\text { compared to control }\end{array}$ & {$[154]$} \\
\hline $\begin{array}{l}\text { Diacron's reactive oxygen } \\
\text { metabolites and total } \\
\text { thiol level }\end{array}$ & Colorectal cancer patients & & $\uparrow$ Diacron's reactive oxygen metabolites, $\downarrow$ total thiol level & {$[155]$} \\
\hline MtDNA copy number & $\begin{array}{l}\text { Acute lymphoblastic } \\
\text { leukaemia patients }\end{array}$ & & $\begin{array}{l}\uparrow \text { mtDNA copy number, } \uparrow \text { mitochondrial deletion ratios, } \downarrow \\
\text { mtDNA copy number after chemotherapy compared to } \\
\text { controls }\end{array}$ & {$[156]$} \\
\hline TOM34 and HSP90AA1 & $\begin{array}{l}\text { Hepatocellular carcinoma } \\
\text { patients }\end{array}$ & Serum & $\uparrow$ TOM34, $\uparrow$ HSP90AA1 compared to cirrhotic patients & {$[157]$} \\
\hline
\end{tabular}

$\uparrow$ Increased

$\downarrow$ Decreased

Abbreviation: $m t D N A$ mitochondrial DNA, PSEN1 presenilin 1, ApoE apolipoprotein E, GSH glutathione, GSSG glutathione disulphide, ATP adenosine triphosphate, $A \beta 42$ the 42 amino acid form of amyloid- $\beta, A P P$ amyloid- $\beta$ precursor protein, $B A C E 1 \beta$-secretase $1, D J 1$ parkin-associated protein involved with oxidative stress, $R O S$ reactive oxygen species, $S O D$ superoxide dismutase, $M D A$ malondialdehyde, ApoC3 apolipoprotein C3, 8OHdG 8hydroxy-2'-deoxyguanosine, TAC total antioxidant capacity, TOM34 34-kDa translocase of the outer mitochondrial membrane, HSP90AA1 heat shock protein 90 alpha family class A member 1 
improved individualised diagnostics and prediction of pathologies associated with mitochondriopathies, especially neurodegenerative disorders, CVDs and cancer.

\section{Conclusions and expert recommendations}

Mitochondrial injury plays a key role in the aetiopathology of multifactorial diseases exhibiting a "vicious circle" characteristic for the mitochondrial and multi-organ damage frequently developed in a reciprocal manner. Although the origin is common (uncontrolled ROS release, diminished energy production and extensive oxidative stress to life-important biomolecules such as mtDNA and chrDNA), individual outcomes differ significantly from each other comprising a spectrum of associated pathologies including but not restricted to the neurodegeneration, CVDs and cancers. Although corresponding pathomechanisms and molecular pathways overlap between individual mitochondriopathy-related pathologies, multi-centre studies demonstrate that, for example, neurodegenerative processes seem to protect against cancer development. In contrast, cancer patients are at greater risk to develop later on Parkinson's or Alzheimer's disease - the phenomenon which hypothetically might be explained by side effects of cancer treatments similarly to a highly increased ischemic stroke incidence well-known for patients with the cancer treatment history. Unfortunately, individual areas currently undergo rather separate investigations that limit their analytical power and create barriers in development of personalised predictive diagnostics and application of cost-effective targeted prevention.

Contextually, the role of predictive, preventive and personalised (PPPM/3P) medicine is to force innovative analytical approaches which would allow for distinguishing between individual outcomes under circumstance of mitochondrial impairments. For that, individualised patient profiling, patient stratification, screening programmes focused on suboptimal health conditions, non-invasive prediction by applying liquid biopsies and cost-effective targeted prevention are instrumental for the paradigm shift from reactive medicine to PPPM. Recent progress made in the area of mitochondriopathies revealed that patient stratification and risk assessment are supportive for the effective treatments considering the level of mitochondrial impairment and individual predisposition to associated pathologies $[158,159]$. General mitigating measures against oxidative damage include application of antioxidant agents with scavenging activity such as phytochemicals $[21,94,160]$, personally adapted physical activities, dietary habits and individualised life-style recommendations [19]. Further, individualised phenotyping is instrumental for screening programmes focused on individuals with reversible damage such as young vasospastic individuals with systemic ischemic-reperfusion effects clearly predisposed to mitochondrial injury and associated pathologies [40, 44, 91].

Last but not the least, acute pandemic conditions require effective predictive, preventive and personalised algorithms for correct decisions made at clinical side. Viral infections are known to provoke necrosis, which amplifies anti-viral immune responses releasing damage-associated molecular patterns. Severely affected cells and tissues intrinsically secrete cell-free nucleic acids such as mtDNA. Indeed, COVID-19 patients with increased mtDNA levels are at elevated death risk and have to be intubated. Consequently, cell-free mtDNA is a potential biomarker for individualised survival status prediction in COVID-19 patients as a model for predictive approach under pandemic conditions [38, 161, 162].

Abbreviations ROS, Reactive oxygen species; mtROS, Mitochondrial reactive oxygen species; PPPM/3PM, Predictive preventive personalised medicine; mtDNA, Mitochondrial DNA; chrDNA, Chromosomal DNA; OXPHO, Oxidative phosphorylation; CVDs, Cardiovascular diseases; BER , Base excision repair; ADAM1, A disintegrin and 71 metalloprotease 10; APP , Amyloid precursor protein; PSEN1, Presenilin 1; PSEN2, Presenilin 2; EMT, Epithelial-mesenchymal transition; Apo, Apolipoprotein; SOD, Superoxide dismutase; ETC, Electron transport chain; DJ1, Parkin-associated protein involved with oxidative stress; HTRA2, Serine peptidase 2; mPTP, Mitochondrial permeability transition pore; ATP, Adenosine triphosphate; PINK1, Putative serine threonine kinase; CytC, Cytochrome $c$; ANT, Adenine nucleotide translocator; CypD, Cyclophilin D; ANT, Adenine nucleotide translocator; NDUFS1, Anti-oxidative enzyme superoxide dismutase 2 and complex I subunit; VDAC, Voltage-dependent anion channel; Parkin, E3 ubiquitin ligase; $\alpha$-syn, $\alpha$-Synuclein; UCHL1, Ubiquitin carboxyterminal hydrolase L1; SH3GL2, SH3 domain containing GRB2 like 2/ endophilin A1; DNAJC6, Auxilin; SYNJ1, Synaptojanin 1; SNpc , Substantia nigra pars compacta; $\mathrm{Ca}^{2+}$, Calcium cation; HIF-1, Hypoxia-inducible factor 1; AKT, Oncogenic protein kinase B; PDH , Pyruvate dehydrogenase; MAPT, Microtubule-associated protein tau; GSH, Glutathione; GSSG, Glutathione disulphide; A $\beta 42$, The 42 amino acid form of amyloid- $\beta$; BACE1, $\beta$-secretase 1; MDA, Malondialdehyde; $8 \mathrm{OHdG}, 8$ Hydroxy-2'-deoxyguanosine; TAC, Total antioxidant capacity; TOM34, $34-\mathrm{kDa}$ translocase of the outer mitochondrial membrane; HSP90AA1, Heat shock protein 90 alpha family class A member 1

Author contribution O.G. was responsible for the paper concepts and PPPM-related contents. The manuscript was drafted by L.K. and P.K. and critically revised by O.G., K.Z., D.B. and F.A.G. The table was created by A.L. Figures was prepared by L.K. and M.S., while P.K. provided a skilled assistance and supervised the overall preparation of the manuscript. All authors have read and agreed to the published version of the manuscript.

Funding Open Access funding enabled and organized by Projekt DEAL. This work was supported by Scientific Grant Agency, VEGA project No.1/0136/19 and a National Priorities Research Programme grant (NPRP 11S-1214-170101; awarded to Professor Dr. Dietrich Büsselberg, June 2019-Current) from the Qatar National Research Fund (QNRF, a member of Qatar Foundation).

Data Availability Not applicable. 
Code availability Not applicable.

\section{Declarations}

Ethics approval Not applicable.

Consent to participate Not applicable.

Consent for publication Not applicable.

Conflict of interest The authors declare no competing interests.

Open Access This article is licensed under a Creative Commons Attribution 4.0 International License, which permits use, sharing, adaptation, distribution and reproduction in any medium or format, as long as you give appropriate credit to the original author(s) and the source, provide a link to the Creative Commons licence, and indicate if changes were made. The images or other third party material in this article are included in the article's Creative Commons licence, unless indicated otherwise in a credit line to the material. If material is not included in the article's Creative Commons licence and your intended use is not permitted by statutory regulation or exceeds the permitted use, you will need to obtain permission directly from the copyright holder. To view a copy of this licence, visit http://creativecommons.org/licenses/by/4.0/.

\section{References}

1. Ploumi C, Daskalaki I, Tavernarakis N. Mitochondrial biogenesis and clearance: a balancing act. FEBS J. 2017;284:183-95. https:// doi.org/10.1111/febs.13820.

2. Nunnari J, Suomalainen A. Mitochondria: in sickness and in health. Cell. 2012;148:1145-59. https://doi.org/10.1016/j.cell. 2012.02.035.

3. Alena L, Marek S, Lenka K, Erik K, Peter K, Olga G. Mitochondriopathies as a clue to systemic disorders: "vicious circle" Of mitochondrial injury, analytical tools and mitigating measures in context of predictive, preventive, and personalized (3P). Medicine. 2021.

4. Faas MM, de Vos P. Mitochondrial function in immune cells in health and disease. Biochim Biophys Acta Mol basis Dis. 1866;2020:165845. https://doi.org/10.1016/j.bbadis.2020. 165845 .

5. Kuznetsov AV, Margreiter R. Heterogeneity of mitochondria and mitochondrial function within cells as another level of mitochondrial complexity. Int J Mol Sci. 2009;10:1911-29. https://doi.org/ 10.3390/ijms 10041911.

6. Kroemer G, Reed JC. Mitochondrial control of cell death. Nat Med. 2000;6:513-9. https://doi.org/10.1038/74994.

7. Kuznetsov AV, Janakiraman M, Margreiter R, Troppmair J. Regulating cell survival by controlling cellular energy production: novel functions for ancient signaling pathways? FEBS Lett. 2004;577:1-4. https://doi.org/10.1016/j.febslet.2004.10.021.

8. McBride HM, Neuspiel M, Wasiak S. Mitochondria: more than just a powerhouse. Curr Biol. 2006;16:R551-60. https://doi.org/ 10.1016/j.cub.2006.06.054.

9. Jang JY, Blum A, Liu J, Finkel T. The role of mitochondria in aging. J Clin Invest. 2018;128:3662-70. https://doi.org/10.1172/ JCI120842.
10. Sato M, Sato K. Degradation of paternal mitochondria by fertilization-triggered autophagy in $\mathrm{C}$ elegans embryos. Science. 2011;334:1141-4. https://doi.org/10.1126/science.1210333.

11. Stockburger C, Eckert S, Eckert GP, Friedland K, Müller WE. Mitochondrial function, dynamics, and permeability transition: a complex love triangle as a possible target for the treatment of brain aging and Alzheimer's disease. J Alzheimers Dis. 2018;64:S45567. https://doi.org/10.3233/JAD-179915.

12. Taghizadeh G, Pourahmad J, Mehdizadeh H, Foroumadi A, Torkaman-Boutorabi A, Hassani S, et al. Protective effects of physical exercise on MDMA-induced cognitive and mitochondrial impairment. Free Radic Biol Med. 2016;99:11-9. https://doi. org/10.1016/j.freeradbiomed.2016.07.018.

13. Chou C-H, Fu T-C, Tsai H-H, Hsu C-C, Wang C-H, Wang J-S. High-intensity interval training enhances mitochondrial bioenergetics of platelets in patients with heart failure. Int $\mathrm{J}$ Cardiol. 2019;274:214-20. https://doi.org/10.1016/j.ijcard.2018.07.104.

14. Hambrecht R, Niebauer J, Fiehn E, Kälberer B, Offner B, Hauer $\mathrm{K}$, et al. Physical training in patients with stable chronic heart failure: effects on cardiorespiratory fitness and ultrastructural abnormalities of leg muscles. J Am Coll Cardiol. 1995;25:1239-49. https://doi.org/10.1016/0735-1097(94)00568-B.

15. van der Zwaard S, de Ruiter CJ, Noordhof DA, Sterrenburg R, Bloemers FW, de Koning JJ, et al. Maximal oxygen uptake is proportional to muscle fiber oxidative capacity, from chronic heart failure patients to professional cyclists. J Appl Physiol (1985). 2016(121):636-45. https://doi.org/10.1152/japplphysiol.00355. 2016.

16. Belardinelli R, Georgiou D, Scocco V, Barstow TJ, Purcaro A. Low intensity exercise training in patients with chronic heart failure. J Am Coll Cardiol. 1995;26:975-82. https://doi.org/10.1016/ 0735-1097(95)00267-1.

17. Hambrecht R, Fiehn E, Yu J, Niebauer J, Weigl C, Hilbrich L, et al. Effects of endurance training on mitochondrial ultrastructure and fiber type distribution in skeletal muscle of patients with stable chronic heart failure. J Am Coll Cardiol. 1997;29:1067-73. https://doi.org/10.1016/s0735-1097(97)00015-6.

18. Williams AD, Carey MF, Selig S, Hayes A, Krum H, Patterson J, et al. Circuit resistance training in chronic heart failure improves skeletal muscle mitochondrial ATP production rate-a randomized controlled trial. J Card Fail. 2007;13:79-85. https://doi.org/10. 1016/j.cardfail.2006.10.017.

19. Kucera R, Pecen L, Topolcan O, Dahal AR, Costigliola V, Giordano FA, et al. Prostate cancer management: long-term beliefs, epidemic developments in the early twenty-first century and 3PM dimensional solutions. EPMA J. 2020;11:399-418. https:// doi.org/10.1007/s13167-020-00214-1.

20. Naoi M, Wu Y, Shamoto-Nagai M, Maruyama W. Mitochondria in neuroprotection by phytochemicals: bioactive polyphenols modulate mitochondrial apoptosis system, function and structure. Int J Mol Sci. 2019;20. https://doi.org/10.3390/ijms20102451.

21. Liskova A, Stefanicka P, Samec M, Smejkal K, Zubor P, Bielik T, et al. Dietary phytochemicals as the potential protectors against carcinogenesis and their role in cancer chemoprevention. Clin Exp Med. 2020;20:173-90. https://doi.org/10.1007/s10238-02000611-w.

22. Kubatka P, Kello M, Kajo K, Samec M, Liskova A, Jasek K, et al. Rhus Coriaria L. (Sumac) demonstrates oncostatic activity in the therapeutic and preventive model of breast carcinoma. Int J Mol Sci. 2020;22:22. https://doi.org/10.3390/ijms22010183.

23. Kubatka U, Kello K, Samec J, et al. Anticancer activities of Thymus vulgaris $\mathrm{L}$. in experimental breast carcinoma in vivo 
and in vitro. IJMS. 2019;20:1749. https://doi.org/10.3390/ ijms20071749.

24. Kubatka P, Kello M, Kajo K, Samec M, Jasek K, Vybohova D, et al. Chemopreventive and therapeutic efficacy of Cinnamomum zeylanicum L. Bark in experimental breast carcinoma: mechanistic in vivo and in vitro analyses. Molecules. 2020;25:1399. https:// doi.org/10.3390/molecules25061399.

25. Ashrafizadeh M, Rafiei H, Mohammadinejad R, Afshar EG, Farkhondeh T, Samarghandian S. Potential therapeutic effects of curcumin mediated by JAK/STAT signaling pathway: a review. Phytother Res. 2020;34:1745-60. https://doi.org/10.1002/ptr. 6642.

26. Ashrafizadeh M, Ahmadi Z, Mohammadinejad R, Ghasemipour AE. Tangeretin: a mechanistic review of its pharmacological and therapeutic effects. J Basic Clin Physiol Pharmacol. 2020;31. https://doi.org/10.1515/jbcpp-2019-0191.

27. Ashrafizadeh M, Ahmadi Z, Farkhondeh T, Samarghandian S. Resveratrol targeting the Wnt signaling pathway: a focus on therapeutic activities. J Cell Physiol. 2020;235:4135-45. https://doi. org/10.1002/jcp.29327.

28. Golubnitschaja O, Baban B, Boniolo G, Wang W, Bubnov R, Kapalla M, et al. Medicine in the early twenty-first century: paradigm and anticipation - EPMA position paper 2016. EPMA Journal. 2016;7:23. https://doi.org/10.1186/s13167-016-0072-4.

29. Collins TJ, Berridge MJ, Lipp P, Bootman MD. Mitochondria are morphologically and functionally heterogeneous within cells. EMBO J. 2002;21:1616-27. https://doi.org/10.1093/emboj/21.7. 1616.

30. de Moura MB, dos Santos LS, Van Houten B. Mitochondrial dysfunction in neurodegenerative diseases and cancer. Environ Mol mutagen. 2010:NA-NA. https://doi.org/10.1002/em.20575.

31. Annesley SJ, Fisher PR. Mitochondria in health and disease. Cells. 2019;8. https://doi.org/10.3390/cells8070680.

32. Balaban RS, Nemoto S, Finkel T. Mitochondria, oxidants, and aging. Cell. 2005;120:483-95. https://doi.org/10.1016/j.cell. 2005.02.001.

33. Hiona A, Sanz A, Kujoth GC, Pamplona R, Seo AY, Hofer T, et al. Mitochondrial DNA mutations induce mitochondrial dysfunction, apoptosis and sarcopenia in skeletal muscle of mitochondrial DNA mutator mice. PLoS One. 2010;5:e11468. https://doi.org/10. 1371/journal.pone.0011468.

34. Sun N, Youle RJ, Finkel T. The mitochondrial basis of aging. Mol Cell. 2016;61:654-66. https://doi.org/10.1016/j.molcel.2016.01. 028.

35. Hepple RT. Mitochondrial involvement and impact in aging skeletal muscle. Front Aging Neurosci. 2014;6:211. https://doi.org/10. 3389/fnagi.2014.00211.

36. Wu NN, Zhang Y, Ren J. Mitophagy, mitochondrial dynamics, and homeostasis in cardiovascular aging. Oxidative Med Cell Longev. 2019;2019:9825061. https://doi.org/10.1155/2019/ 9825061.

37. Chen AX, Conti TF, Hom GL, Greenlee TE, Raimondi R, Briskin IN, et al. Functional imaging of mitochondria in retinal diseases using flavoprotein fluorescence. Eye. 2021;35:74-92. https://doi. org/10.1038/s41433-020-1110-y.

38. Crigna AT, Samec M, Koklesova L, Liskova A, Giordano FA, Kubatka P, et al. Cell-free nucleic acid patterns in disease prediction and monitoring - hype or hope? EPMA Journal. 2020;11: 603-27. https://doi.org/10.1007/s13167-020-00226-x.

39. Gerner C, Costigliola V, Golubnitschaja O. Multiomic patterns in body fluids: technological challenge with a great potential to implement the advanced paradigm of 3P medicine. Mass Spectrom Rev. 2019. https://doi.org/10.1002/mas.21612.
40. Polivka J, Polivka J, Pesta M, Rohan V, Celedova L, Mahajani S, et al. Risks associated with the stroke predisposition at young age: facts and hypotheses in light of individualized predictive and preventive approach. EPMA J. 2019;10:81-99. https://doi.org/10. 1007/s13167-019-00162-5.

41. Golubnitschaja O, Flammer J. What are the biomarkers for Glaucoma? Surv Ophthalmol. 2007;52(Suppl 2):S155-61. https://doi.org/10.1016/j.survophthal.2007.08.011.

42. Golubnitschaja O. The Keyrole of multiomics in the predictive, preventive and personalised medical approach towards Glaucoma management. Klin Monatsbl Augenheilkd. 2018;235:146-50. https://doi.org/10.1055/s-0044-101164.

43. Yeghiazaryan K, Flammer J, Golubnitschaja O. Predictive molecular profiling in blood of healthy vasospastic individuals: clue to targeted prevention as personalised medicine to effective costs. EPMA Journal. 2010;1:263-72. https://doi.org/10.1007/s13167010-0032-3.

44. Golubnitschaja O, editor. Flammer syndrome: From phenotype to associated pathologies, prediction, prevention and personalisation. Advances in predictive, preventive and personalised medicine. New York: Springer International Publishing; 2019.

45. Oboudiyat C, Glazer H, Seifan A, Greer C, Isaacson RS. Alzheimer's disease. Semin Neurol. 2013;33:313-29. https:// doi.org/10.1055/s-0033-1359319.

46. Hardy JA, Higgins GA. Alzheimer's disease: the amyloid Cascade hypothesis. Science. 1992;256:184-5. https://doi.org/10.1126/ science. 1566067.

47. Kozlov S, Afonin A, Evsyukov I, Bondarenko A. Alzheimer's disease: as it was in the beginning. Rev Neurosci. 2017;28:82543. https://doi.org/10.1515/revneuro-2017-0006.

48. Zhu J-B, Tan C-C, Tan L, Yu J-T. State of play in Alzheimer's disease genetics. J Alzheimers Dis. 2017;58:631-59. https://doi. org/10.3233/JAD-170062.

49. Pavlov P, Wiehager B, Sakai J, Frykman S, Behbahani H, Winblad B, et al. Mitochondrial -secretase participates in the metabolism of mitochondria-associated amyloid precursor protein. FASEB Journal : official publication of the Federation of American Societies for Experimental Biology. 2011;25:78-88. https://doi.org/10.1096/fj.10-157230.

50. Mahley RW, Huang Y. Apolipoprotein E sets the stage: response to injury triggers neuropathology. Neuron. 2012;76:871-85. https://doi.org/10.1016/j.neuron.2012.11.020.

51. Sarasija S, Norman KR. Role of Presenilin in mitochondrial oxidative stress and neurodegeneration in Caenorhabditis Elegans. Antioxidants (Basel). 2018;7. https://doi.org/10.3390/ antiox 7090111.

52. Vassar R. ADAM10 Prodomain mutations cause late-onset Alzheimer's disease: not just the latest FAD. Neuron. 2013;80: 250-3. https://doi.org/10.1016/j.neuron.2013.09.031.

53. Bose A, Beal MF. Mitochondrial dysfunction in Parkinson's disease. J Neurochem. 2016;139(Suppl 1):216-31. https://doi.org/10. 1111/jnc. 13731.

54. Balestrino R, Schapira AHV. Parkinson disease. Eur J Neurol. 2020;27:27-42. https://doi.org/10.1111/ene.14108.

55. Cesari R, Martin ES, Calin GA, Pentimalli F, Bichi R, McAdams $\mathrm{H}$, et al. Parkin, a gene implicated in autosomal recessive juvenile parkinsonism, is a candidate tumor suppressor gene on chromosome 6q25-Q27. Proc Natl Acad Sci U S A. 2003;100:5956-61. https://doi.org/10.1073/pnas.0931262100.

56. Dawson TM, Dawson VL. Rare genetic mutations shed light on the pathogenesis of Parkinson disease. J Clin Invest. 2003;111: 145-51. https://doi.org/10.1172/JCI17575. 
57. Gómez-Benito M, Granado N, García-Sanz P, Michel,A, Dumoulin M, Moratalla R. Modeling Parkinson's disease with the alpha-Synuclein protein. Front Pharmacol 2020; 11. https:// doi.org/10.3389/fphar.2020.00356.

58. Nguyen M, Wong YC, Ysselstein D, Severino A, Krainc D. Synaptic, mitochondrial, and lysosomal dysfunction in Parkinson's disease. Trends Neurosci. 2019;42:140-9. https:// doi.org/10.1016/j.tins.2018.11.001.

59. Larsen SB, Hanss Z, Krüger R. The genetic architecture of mitochondrial dysfunction in Parkinson's disease. Cell Tissue Res. 2018;373:21-37. https://doi.org/10.1007/s00441-017-2768-8.

60. Faustini G, Bono F, Valerio A, Pizzi M, Spano P, Bellucci A. Mitochondria and $\alpha$-Synuclein: friends or foes in the pathogenesis of Parkinson's disease? Genes (Basel). 2017;8. https://doi.org/10. 3390/genes8120377.

61. Takahashi-Niki K, Niki T, Iguchi-Ariga S, Ariga H. Function of DJ-1 in mitochondria. Yakugaku Zasshi. 2012;132:1105-10. https://doi.org/10.1248/yakushi.12-00220-3.

62. Durcan TM, Fon EA. The three 'P's of Mitophagy: PARKIN, PINK1, and post-translational modifications. Genes Dev. 2015;29:989-99. https://doi.org/10.1101/gad.262758.115.

63. Chen S, Sanislav O, Annesley SJ, Fisher PR. Mitochondrial HTRA2 plays a positive, protective role in Dictyostelium Discoideum but is cytotoxic when overexpressed. Genes (Basel). 2018;9. https://doi.org/10.3390/genes9070355.

64. Corsetti V, Florenzano F, Atlante A, Bobba A, Ciotti MT, Natale F, et al. NH2-truncated human tau induces deregulated Mitophagy in neurons by aberrant recruitment of Parkin and UCHL-1: implications in Alzheimer's disease. Hum Mol Genet. 2015;24:305881. https://doi.org/10.1093/hmg/ddv059.

65. Roth GA, Johnson C, Abajobir A, Abd-Allah F, Abera SF, Abyu $\mathrm{G}$, et al. Global, regional, and National Burden of cardiovascular diseases for 10 causes, 1990 to 2015. J Am Coll Cardiol. 2017;70: 1-25. https://doi.org/10.1016/j.jacc.2017.04.052.

66. Kralj V, Brkić BI. Morbidity and mortality from cardiovascular diseases. Cardiologia Croatica. 2013;8:373-8.

67. Gaziano JM. Global burden of cardiovascular disease. In: Braunwald's heart disease: a textbook of cardiovascular medicine. 7th ed. Bonow R.M. \& Braunwald E: Zipes D.M., Libby P; 2005. p. 1-19.

68. European Association for Cardiovascular Prevention \& Rehabilitation, Reiner Z, Catapano AL, De Backer G, Graham I, Taskinen M-R, Wiklund O, Agewall S, Alegria E, Chapman MJ et al. ESC/EAS guidelines for the Management of Dyslipidaemias: the task force for the Management of Dyslipidaemias of the European Society of Cardiology (ESC) and the European atherosclerosis society (EAS). Eur Heart J. 2011; 32:1769-1818. https://doi.org/10.1093/eurheartj/ehr158.

69. Saeed A, Kampangkaew J, Nambi V. Prevention of cardiovascular disease in women. Methodist Debakey Cardiovasc J. 2017;13: 185-92. https://doi.org/10.14797/mdcj-13-4-185.

70. Chistiakov DA, Shkurat TP, Melnichenko AA, Grechko AV, Orekhov AN. The role of mitochondrial dysfunction in cardiovascular disease: a brief review. Ann Med. 2018;50:121-7. https:// doi.org/10.1080/07853890.2017.1417631.

71. Koene S, Smeitink J. Mitochondrial medicine: entering the era of treatment. J Intern Med. 2009;265:193-209. https://doi.org/10. 1111/j.1365-2796.2008.02058.x.

72. Jusic A, Devaux Y. EU-CardioRNA COST action (CA17129) mitochondrial noncoding RNA-regulatory network in cardiovascular disease. Basic Res Cardiol. 2020;115:23. https://doi.org/10. 1007/s00395-020-0783-5.
73. Baumgartner HK, Gerasimenko JV, Thorne C, Ferdek P, Pozzan $\mathrm{T}$, Tepikin AV, et al. Calcium elevation in mitochondria is the Main $\mathrm{Ca} 2+$ requirement for mitochondrial permeability transition pore (MPTP) opening. J Biol Chem. 2009;284:20796-803. https://doi.org/10.1074/jbc.M109.025353.

74. Zorov DB, Juhaszova M, Sollott SJ. Mitochondrial reactive oxygen species (ROS) and ROS-induced ROS release. Physiol Rev. 2014;94:909-50. https://doi.org/10.1152/physrev.00026.2013.

75. Holmgren D, Wåhlander H, Eriksson BO, Oldfors A, Holme E, Tulinius M. Cardiomyopathy in children with mitochondrial disease; clinical course and Cardiological findings. Eur Heart J. 2003;24:280-8. https://doi.org/10.1016/s0195-668x(02)00387-1.

76. Dominic EA, Ramezani A, Anker SD, Verma M, Mehta N, Rao M. Mitochondrial Cytopathies and cardiovascular disease. Heart. 2014;100:611-8. https://doi.org/10.1136/heartjnl-2013-304657.

77. Kaski J-C, Crea F, Gersh BJ, Camici PG. Reappraisal of ischemic heart disease. Circulation. 2018;138:1463-80. https://doi.org/10. 1161/CIRCULATIONAHA.118.031373.

78. Chen Q, Camara AKS, Stowe DF, Hoppel CL, Lesnefsky EJ. Modulation of Electron transport protects cardiac mitochondria and decreases myocardial injury during ischemia and reperfusion. Am J Physiol Cell Physiol. 2007;292:C137-47. https://doi.org/10. 1152/ajpcell.00270.2006.

79. Buja LM. The pathobiology of acute coronary syndromes: clinical implications and central role of the mitochondria. Tex Heart Inst J. 2013;40:221-8.

80. Goldenthal MJ. Mitochondrial involvement in myocyte death and heart failure. Heart Fail Rev. 2016;21:137-55. https://oi.org/10. 1007/s10741-016-9531-1.

81. Webster KA. Mitochondrial death channels. Am Sci. 2009;97: 384-91. https://doi.org/10.1511/2009.80.384.

82. Zhou B, Tian R. Mitochondrial dysfunction in pathophysiology of heart failure. J Clin Invest. 2018;128:3716-26. https://doi.org/10. 1172/JCI120849.

83. Karamanlidis G, Nascimben L, Couper GS, Shekar PS, del Monte F, Tian R. Defective DNA replication impairs mitochondrial biogenesis in human failing hearts. Circ Res 2010;106:1541-1548. https://doi.org/10.1161/CIRCRESAHA.109.212753.

84. Marin-Garcia J, Goldenthal MJ, Moe GW. Mitochondrial pathology in cardiac failure. Cardiovasc Res. 2001;49:17-26. https://doi. org/10.1016/S0008-6363(00)00241-8.

85. Allard MF, Schönekess BO, Henning SL, English DR, Lopaschuk GD. Contribution of oxidative metabolism and glycolysis to ATP production in hypertrophied hearts. Am J Phys. 1994;267:H74250. https://doi.org/10.1152/ajpheart.1994.267.2.H742.

86. Tayal,U, Prasad S, Cook SA. Genetics and genomics of dilated cardiomyopathy and systolic heart failure. Genome Med 2017; 9. https://doi.org/10.1186/s13073-017-0410-8.

87. Garnham JO, Roberts LD, Espino-Gonzalez E, Whitehead A, Swoboda PP, Koshy A, et al. Chronic heart failure with diabetes mellitus is characterized by a severe skeletal muscle pathology. J Cachexia Sarcopenia Muscle. 2020;11:394-404. https://doi.org/ $10.1002 /$ jcsm. 12515.

88. Koklesova L, Liskova A, Samec M, Zhai K, Abotaleb M, Ashrafizadeh M, et al. Carotenoids in Cancer metastasis-status quo and outlook. Biomolecules. 2020;10. https://doi.org/10. 3390/biom10121653.

89. Safarzadeh E, Sandoghchian Shotorbani S, Baradaran B. Herbal medicine as inducers of apoptosis in Cancer treatment. Adv Pharm Bull. 2014;4:421-7. https://doi.org/10.5681/apb.2014.062.

90. Dagogo-Jack I, Shaw AT. Tumour heterogeneity and resistance to Cancer therapies. Nat Rev Clin Oncol. 2018;15:81-94. https://doi. org/10.1038/nrclinonc.2017.166. 
91. Kunin A, Sargheini N, Birkenbihl C, Moiseeva N, Fröhlich H, Golubnitschaja O. Voice perturbations under the stress overload in young individuals: phenotyping and suboptimal health as predictors for cascading pathologies. EPMA J. 2020:1-11. https:// doi.org/10.1007/s13167-020-00229-8.

92. Goldstein E, Yeghiazaryan K, Ahmad A, Giordano FA, Fröhlich $\mathrm{H}$, Golubnitschaja O. Optimal multiparametric set-up modelled for best survival outcomes in palliative treatment of liver malignancies: unsupervised machine learning and 3PM recommendations. EPMA J. 2020;11:505-15. https://doi.org/10.1007/s13167020-00221-2.

93. Samec M, Liskova A, Koklesova L, Samuel SM, Zhai K, Buhrmann C, et al. Flavonoids against the Warburg phenotypeconcepts of predictive, preventive and personalised medicine to cut the Gordian knot of Cancer cell metabolism. EPMA J. 2020;11:377-98. https://doi.org/10.1007/s13167-020-00217-y.

94. Koklesova L, Liskova A, Samec M, Qaradakhi T, Zulli A, Smejkal K, et al. Genoprotective activities of plant natural substances in Cancer and Chemopreventive strategies inthe context of 3P medicine. EPMA Journal. 2020;11:261-87. https://doi.org/10. 1007/s13167-020-00210-5.

95. Qian S, Golubnitschaja O, Zhan X. Chronic inflammation: key player and biomarker-set to predict and prevent Cancer development and progression based on individualized patient profiles. EPMA J. 2019;10:365-81. https://doi.org/10.1007/s13167-01900194-x.

96. Goncharenko V, Bubnov R, Polivka J, Zubor P, Biringer K, Bielik $\mathrm{T}$, et al. Vaginal dryness: individualised patient profiles. Risks and Mitigating Measures EPMA J. 2019;10:73-9. https://doi.org/10. 1007/s13167-019-00164-3.

97. Garber JE, Offit K. Hereditary Cancer predisposition syndromes. J Clin Oncol. 2005;23:276-92. https://doi.org/10.1200/JCO.2005. 10.042 .

98. Golubnitschaja O, Debald M, Yeghiazaryan K, Kuhn W, Pešta M, Costigliola V, et al. Breast Cancer epidemic in the early twentyfirst century: evaluation of risk factors, cumulative questionnaires and recommendations for preventive measures. Tumor Biol. 2016;37:12941-57. https://doi.org/10.1007/s13277-016-5168-x.

99. Polyak K, Li Y, Zhu H, Lengauer C, Willson JK, Markowitz SD, et al. Somatic mutations of the mitochondrial genome in human colorectal Tumours. Nat Genet. 1998;20:291-3. https://doi.org/ $10.1038 / 3108$.

100. Fliss MS, Usadel H, Caballero OL, Wu L, Buta MR, Eleff SM, et al. Facile detection of mitochondrial DNA mutations in tumors and bodily fluids. Science. 2000;287:2017-9. https://doi.org/10. 1126/science.287.5460.2017.

101. Carew JS, Huang P. Mitochondrial defects in Cancer. Mol Cancer. 2002;1:9. https://doi.org/10.1186/1476-4598-1-9.

102. Copeland WC, Wachsman JT, Johnson FM, Penta JS. Mitochondrial DNA alterations in Cancer. Cancer Investig. 2002;20:557-69. https://doi.org/10.1081/cnv-120002155.

103. Brandon M, Baldi P, Wallace DC. Mitochondrial mutations in Cancer. Oncogene. 2006;25:4647-62. https://doi.org/10.1038/sj. onc. 1209607.

104. Hsu C-C, Tseng L-M, Lee H-C. Role of mitochondrial dysfunction in Cancer progression. Exp Biol Med (Maywood). 2016;241: 1281-95. https://doi.org/10.1177/1535370216641787.

105. Garcia-Heredia JM, Carnero A. Decoding Warburg's hypothesis: tumor-related mutations in the mitochondrial respiratory chain. Oncotarget. 2015;6:41582-99. https://doi.org/10.18632/ oncotarget.6057.

106. Spencer NY, Stanton RC. The Warburg effect, lactate, and nearly a century of trying to cure Cancer. Semin Nephrol. 2019;39:380 93. https://doi.org/10.1016/j.semnephrol.2019.04.007.

107. Guerra F, Guaragnella N, Arbini AA, Bucci C, Giannattasio S, Moro L. Mitochondrial dysfunction: a novel potential Driver of epithelial-to-mesenchymal transition in Cancer. Front Oncol. 2017;7. https://doi.org/10.3389/fonc.2017.00295.

108. Schmidt LS, Linehan WM. Hereditary Leiomyomatosis and renal cell carcinoma. Int J Nephrol Renovasc Dis. 2014;7:253-60. https://doi.org/10.2147/IJNRD.S42097.

109. Cairns RA, Mak TW. Oncogenic Isocitrate dehydrogenase mutations: mechanisms, models, and clinical opportunities. Cancer Discov. 2013;3:730-41. https://doi.org/10.1158/2159-8290.CD13-0083.

110. Bardella C, Pollard PJ, Tomlinson I. SDH mutations in Cancer. Biochim Biophys Acta. 1807;2011:1432-43. https://doi.org/10. 1016/j.bbabio.2011.07.003.

111. Fujiwara M, Marusawa H, Wang H-Q, Iwai A, Ikeuchi K, Imai Y, et al. Parkin as a tumor suppressor gene for hepatocellular carcinoma. Oncogene. 2008;27:6002-11. https://doi.org/10.1038/onc. 2008.199.

112. Plun-Favreau H, Lewis PA, Hardy J, Martins LM, Wood NW. Cancer and neurodegeneration: between the devil and the deep Blue Sea. PLoS Genet. 2010;6:e1001257. https://doi.org/10. 1371/journal.pgen.1001257.

113. Israeli E, Yakunin E, Zarbiv Y, Hacohen-Solovich A, Kisos H, Loeb $\mathrm{V}$, et al. $\alpha$-Synuclein expression selectively affects tumorigenesis in mice modeling Parkinson's disease. PLoS One. 2011;6: e19622. https://doi.org/10.1371/journal.pone.0019622.

114. Pérez MJ, Jara C, Quintanilla RA. Contribution of tau pathology to mitochondrial impairment in neurodegeneration. Front Neurosci. 2018;12. https://doi.org/10.3389/fnins.2018.00441.

115. Sekino Y, Han X, Babasaki T, Goto K, Inoue S, Hayashi T, et al. Microtubule-associated protein tau (MAPT) promotes Bicalutamide resistance and is associated with survival in prostate Cancer. Urol Oncol. 2020;38(795):e1-795.e8. https://doi.org/10. 1016/j.urolonc.2020.04.032.

116. Hadrava Vanova K, Kraus M, Neuzil J, Rohlena J. Mitochondrial complex II and reactive oxygen species in disease and therapy. Redox Rep. 2020;25:26-32. https://doi.org/10.1080/13510002. 2020.1752002.

117. D'Amelio M, Ragonese P, Sconzo G, Aridon P, Savettieri G. Parkinson's disease and Cancer: insights for pathogenesis from epidemiology. Ann N Y Acad Sci. 2009;1155:324-34. https:// doi.org/10.1111/j.1749-6632.2008.03681.x.

118. Driver JA, Logroscino G, Buring JE, Gaziano JM, Kurth T. A prospective cohort study of Cancer incidence following the diagnosis of Parkinson's disease. Cancer Epidemiol Biomark Prev. 2007;16:1260-5. https://doi.org/10.1158/1055-9965.EPI-070038 .

119. Zanetti R, Rosso S, Loria DI. Parkinson's disease and cancer. Cancer Epidemiol Biomark Prev. 2007;16:1081-1. https://doi. org/10.1158/1055-9965.EPI-07-0377.

120. Elbaz A, Peterson BJ, Yang P, Van Gerpen JA, Bower JH, Maraganore DM, McDonnell SK, Ahlskog JE, Rocca WA. Nonfatal cancer preceding parkinson's disease: a case-control study. Epidemiology. 2002;13:157-164. https://doi.org/10.1097/ 00001648-200203000-00010.

121. Chen C, Zheng H, Hu Z. Association between parkinson's disease and risk of prostate cancer in different populations: an updated meta-analysis. Sci Rep. 2017;7. https://doi.org/10.1038/s41598017-13834-x10.1038/s41598-017-13834-x.

122. Papageorgakopoulos TN, Moraitou D, Papanikolaou M, Tsolaki $\mathrm{M}$. The association between Alzheimer's disease and cancer: systematic review - meta-analysis. Hell J Nucl Med. 2017;20(Suppl): 45-57.

123. Shi H, Tang B, Liu Y-W, Wang X-F, Chen G-J. Alzheimer disease and cancer risk: a meta-analysis. J Cancer Res Clin Oncol. 2015;141:485-94. https://doi.org/10.1007/s00432-014-1773-5.

124. Ma L-L, Yu J-T, Wang H-F, Meng X-F, Tan C-C, Wang C, et al. Association between cancer and alzheimer's disease: systematic 
review and meta-analysis. J Alzheimers Dis. 2014;42:565-73. https://doi.org/10.3233/JAD-140168.

125. Ording AG, Veres K, Horváth-Puhó E, Glymour MM, Rørth M, Henderson VW, et al. Alzheimer's and parkinson's diseases and the risk of cancer: a cohort study. JAD. 2019;72:1269-77. https:// doi.org/10.3233/JAD-190867.

126. Zhang P, Liu B. Association between Parkinson's disease and risk of cancer: a PRISMA-compliant meta-analysis. ACS Chem Neurosci. 2019;10:4430-9. https://doi.org/10.1021/ acschemneuro.9b00498.

127. Catalá-López F, Suárez-Pinilla M, Suárez-Pinilla P, Valderas JM, Gómez-Beneyto M, Martinez S, et al. Inverse and direct cancer comorbidity in people with central nervous system disorders: a meta-analysis of cancer incidence in 577,013 participants of 50 observational studies. Psychother Psychosom. 2014;83:89-105. https://doi.org/10.1159/000356498.

128. Zaorsky NG, Zhang Y, Tchelebi LT, Mackley HB, Chinchilli VM, Zacharia BE. Stroke among cancer patients. Nat Commun. 2019;10:5172. https://doi.org/10.1038/s41467-019-13120-6.

129. Balakumar P, Maung-U K, Jagadeesh G. Prevalence and prevention of cardiovascular disease and diabetes mellitus. Pharmacol Res. 2016;113:600-9. https://doi.org/10.1016/j.phrs.2016.09.040.

130. Meijers WC, de Boer RA. Common risk factors for heart failure and cancer. Cardiovasc Res 2019;115:844-853. https://doi.org/10. 1093/cvr/cvz035.

131. Koene RJ, Prizment AE, Blaes A, Konety SH. Shared risk factors in cardiovascular disease and cancer. Circulation. 2016;133:1104 14. https://doi.org/10.1161/CIRCULATIONAHA.115.020406.

132. Podlesniy P, Figueiro-Silva J, Llado A, Antonell A, SanchezValle R, Alcolea D, et al. Low cerebrospinal fluid concentration of mitochondrial dna in preclinical alzheimer disease. Ann Neurol. 2013;74:655-68. https://doi.org/10.1002/ana.23955.

133. Llano DA, Bundela S, Mudar RA, Devanarayan V. Alzheimer's Disease Neuroimaging Initiative (ADNI) a multivariate predictive modeling approach reveals a novel csf peptide signature for both alzheimer's disease state classification and for predicting future disease progression. PLoS One. 2017;12:e0182098. https://doi. org/10.1371/journal.pone.0182098.

134. Kosenko EA, Aliev G, Kaminsky YG. Relationship between chronic disturbance of 2,3-diphosphoglycerate metabolism in erythrocytes and alzheimer disease. CNS Neurol Disord Drug Targets. 2016;15:113-23. https://doi.org/10.2174/ 1871527314666150821103444 .

135. Skoumalová A, Ivica J, Santorová P, Topinková E, Wilhelm J. The lipid peroxidation products as possible markers of alzheimer's disease in blood. Exp Gerontol. 2011;46:38-42. https://doi.org/10. 1016/j.exger.2010.09.015.

136. Jia J, Hu J, Huo X, Miao R, Zhang Y, Ma F. Effects of vitamin D supplementation on cognitive function and blood a $\beta$-related biomarkers in older adults with alzheimer's disease: a randomised, double-blind. Placebo-Controlled Trial J Neurol Neurosurg Psychiatry. 2019;90:1347-52. https://doi.org/10.1136/jnnp-2018320199.

137. Peña-Bautista $C$, Tirle $T$, López-Nogueroles $M$, Vento $M$, Baquero M, Cháfer-Pericás C. Oxidative damage of DNA as early marker of alzheimer's disease. Int J Mol Sci. 2019;20. https://doi. org/10.3390/ijms20246136.

138. Munzar M, Levy S, Rush R, Averback P. Clinical study of a urinary competitve ELISA for neural thread protein in alzheimer disease. Neurol Clin Neurophysiol. 2002;2002:2-8. https://doi. org/10.1162/15268740252769709.

139. Herbert MK, Eeftens JM, Aerts MB, Esselink RAJ, Bloem BR, Kuiperij HB, et al. CSF levels of DJ-1 and tau distinguish MSA patients from PD patients and controls. Parkinsonism Relat Disord. 2014;20:112-5. https://doi.org/10.1016/j.parkreldis. 2013.09.003.
140. García-Moreno J-M, Martín de Pablos A, García-Sánchez M-I, Méndez-Lucena C, Damas-Hermoso F, Rus M, et al. May serum levels of advanced oxidized protein products serve as a prognostic marker of disease duration in patients with idiopathic parkinson's disease? Antioxid Redox Signal. 2013;18:1296-302. https://doi. org/10.1089/ars.2012.5026.

141. Smith AM, Depp C, Ryan BJ, Johnston GI, Alegre-Abarrategui J, Evetts S, et al. Mitochondrial dysfunction and increased glycolysis in prodromal and early parkinson's blood cells. Mov Disord. 2018;33:1580-90. https://doi.org/10.1002/mds.104.

142. Vida C, Kobayashi H, Garrido A, Martínez de Toda I, Carro E, Molina JA, et al. Lymphoproliferation impairment and oxidative stress in blood cells from early parkinson's disease patients. Int J Mol Sci. 2019;20. https://doi.org/10.3390/ijms20030771.

143. Pellecchia MT, Savastano R, Moccia M, Picillo M, Siano P, Erro $\mathrm{R}$, et al. Lower serum uric acid is associated with mild cognitive impairment in early parkinson's disease: a 4-year follow-up study. J Neural Transm (Vienna). 2016;123:1399-402. https://doi.org/ 10.1007/s00702-016-1622-6.

144. Luan H, Liu L-F, Tang Z, Mok VCT, Li M, Cai Z. Elevated excretion of biopyrrin as a new marker for idiopathic parkinson's disease. Parkinsonism Relat Disord. 2015;21:1371-2. https://doi. org/10.1016/j.parkreldis.2015.09.009.

145. Wang Y, Shen L, Xu D. Aerobic exercise reduces triglycerides by targeting apolipoprotein $\mathrm{C} 3$ in patients with coronary heart disease. Clin Cardiol. 2018;42:56-61. https://doi.org/10.1002/clc. 23104.

146. Peacock WF, De Marco T, Fonarow GC, Diercks D, Wynne J, Apple FS, Wu AHB. ADHERE investigators cardiac troponin and outcome in acute heart failure. N Engl J Med 2008;358:21172126. https://doi.org/10.1056/NEJMoa0706824.

147. Richards AM, Doughty R, Nicholls MG, MacMahon S, Sharpe N, Murphy J, et al. Australia-New Zealand heart failure group plasma n-terminal pro-brain natriuretic peptide and adrenomedullin: prognostic utility and prediction of benefit from carvedilol in chronic ischemic left ventricular dysfunction. Australia-New Zealand heart failure group. J Am Coll Cardiol. 2001;37:1781-7. https:// doi.org/10.1016/s0735-1097(01)01269-4.

148. Feldman AM, Mann DL, She L, Bristow MR, Maisel AS, McNamara DM, et al. Prognostic significance of biomarkers in predicting outcome in patients with coronary artery disease and left ventricular dysfunction: results of the biomarker substudy of the surgical treatment for ischemic heart failure trials. Circ Heart Fail. 2013;6:461-72. https://doi.org/10.1161/ CIRCHEARTFAILURE.112.000185.

149. Folsom AR, Gottesman RF, Appiah D, Shahar E, Mosley TH. Plasma D-dimer and incident ischemic stroke and coronary heart disease: the atherosclerosis risk in communities study. Stroke. 2016;47:18-23. https://doi.org/10.1161/STROKEAHA.115. 011035 .

150. Vilades D, Martínez-Camblor P, Ferrero-Gregori A, Bär C, Lu D, Xiao K, et al. Plasma circular RNA Hsa_circ_0001445 and coronary artery disease: performance as a biomarker. FASEB J. 2020;34:4403-14. https://doi.org/10.1096/fj.201902507R.

151. Wang L, Shen C, Wang Y, Zou T, Zhu H, Lu X, et al. Identification of circular RNA Hsa_circ_0001879 and Hsa_circ_0004104 as novel biomarkers for coronary artery disease. Atherosclerosis. 2019;286:88-96. https://doi.org/10.1016/j. atherosclerosis.2019.05.006.

152. Antosova M, Bencova A, Mikolka P, Kosutova P, Mokrá D, Rozborilová E. The markers of oxidative stress in patient with lung cancer. Eur Respir J. 2015;46. https://doi.org/10.1183/ 13993003.congress-2015.PA4267.

153. Shukla S, Srivastava JK, Shankar E, Kanwal R, Nawab A, Sharma $\mathrm{H}$, et al. Oxidative stress and antioxidant status in high-risk 
prostate cancer subjects. Diagnostics (Basel). 2020;10. https://doi. org/10.3390/diagnostics10030126.

154. Hewala TI, Elsoud MRA. The clinical significance of serum oxidative stress biomarkers in breast cancer females. Med Res J. 2019;4:1-7. https://doi.org/10.5603/MRJ.a2018.0039.

155. Boakye D, Jansen L, Schöttker B, Jansen EHJM, Schneider M, Halama N, et al. Blood markers of oxidative stress are strongly associated with poorer prognosis in colorectal cancer patients. Int J Cancer. 2020;147:2373-86. https://doi.org/10.1002/ijc.33018.

156. Jain A, Bakhshi S, Thakkar H, Gerards M, Singh A. Elevated mitochondrial DNA copy numbers in pediatric acute lymphoblastic leukemia: a potential biomarker for predicting inferior survival. Pediatr Blood Cancer. 2018;65. https://doi.org/10.1002/pbc. 26874.

157. Toraih EA, Alrefai HG, Hussein MH, Helal GM, Khashana MS, Fawzy MS. Overexpression of heat shock protein HSP90AA1 and translocase of the outer mitochondrial membrane TOM34 in HCV-induced hepatocellular carcinoma: a pilot study. Clin Biochem. 2019;63:10-7. https://doi.org/10.1016/j.clinbiochem. 2018.12.001.

158. Borsche M, Pereira SL, Klein C, Grünewald A. Mitochondria and parkinson's disease: clinical, molecular, and translational aspects. J Parkinsons Dis. 2020. https://doi.org/10.3233/JPD-201981.
159. Frančula-Zaninović S, Nola IA. Management of measurable variable cardiovascular disease' risk factors. Curr Cardiol Rev. $2018 ; 14: 153-63$. https://doi.org/10.2174/ $1573403 X 14666180222102312$.

160. Koklesova L, Liskova A, Samec M, Buhrmann C, Samuel SM, Varghese E, et al. Carotenoids in cancer apoptosis - the road from bench to bedside and back. Cancers (Basel). 2020;12. https://doi. org/10.3390/cancers12092425.

161. Scozz D, Cano M, Ma L, Zhou D, Zhu JH, O’Halloran JA, et al. Circulating mitochondrial DNA is an early indicator of severe illness and mortality from COVID-19. bioRxiv. 2020. https:// doi.org/10.1101/2020.07.30.227553.

162. Chaari L, Golubnitschaja O. Covid-19 pandemic by the "realtime" monitoring: the tunisian case and lessons for global epidemics in the context of 3PM strategies. EPMA Journal. 2020;11:133-8. https://doi.org/10.1007/s13167-020-00207-0.

Publisher's note Springer Nature remains neutral with regard to jurisdictional claims in published maps and institutional affiliations. 